Revista Iberoamericana. Vol. LXVI, Núm. 191, Abril-Junio 2000, 425-428

\title{
ISAAC GOLDEMBERG \\ EL GRAN LIBRO DE LA AMÉRICA JUDÍA
}

\author{
POR \\ MaRgo GLANTZ \\ Universidad Nacional Autónoma de México
}

¿Qué tiene de particular este Gran libro de la América judía? Estoy segura de que por lo menos delimita una nueva territorialidad y una nueva versión lingüística del judaísmo: un ámbito geográfico conocido desde 1492 hasta principios del siglo XIX como el territorio de las Indias, cuyos idiomas eran y son aún el español y el portugués y varias lenguas indígenas, y también poblado por judíos españoles o portugueses refugiados en estas tierras huyendo de la inquisición y más tarde por judíos europeos y del Medio Oriente que, de nuevo, tuvieron que aprender el español y el portugués. ¿Qué relación con los otros judíos, los de la antigua Europa perseguida y devastada por el nazismo? ¿Qué cercanía con los judíos de las otras diásporas: Estados Unidos o la actual Europa? ¿Y con el estado de Israel qué...?

Primero, es necesario aclarar que esta antología se conforma de manera diferente a las antologías tradicionales y adopta una nueva figura cuyo sentido no es la separación cronológica o territorial de los antologados, sino la creación de un texto colectivo en donde los autores encuentran una voz distinta a la suya y entonan una voz colectiva que amalgama los textos y los integra originando un solo e inmenso escrito, o exagerando un poco, pero a guisa de ejemplo, parecido a esas versiones diversas del Libro de los Libros, la Torah, que se leen como si la Biblia hubiese sido escrita por un solo amanuense divino y como si las distintas épocas y autores se confundiesen sin temporalidad ni individualidad ninguna, o como si se tratase de distintos capítulos que narrasen la historia de un pueblo o que organizasen una codificación de sus leyes y sus ceremonias.

Isaac Goldemberg ha dividido este gran Libro — literalmente grande - en capítulos llamados asimismo libros y los ha clasificado siguiendo la ordenación del alfabeto hebreo, haciendo combinaciones, en su afán de revisar y condensar los orígenes, como un nuevo génesis de esta nueva diáspora con sus sucesivas dispersiones, esos éxodos y errancias perpetuas del pueblo judío. Los capítulos visitan los espacios sagrados y los profanos, los mitos y las ceremonias, los altares familiares, los retratos y los autorretratos, los muertos, los sueños, los números y las letras, los amores y desamores, Dios, Jehovah y Jesús, el humor, los comentarios, parte fundamental de la tradición judía, la tradición del Talmud y la Cabalística.

Nuevo territorio, otras lenguas y ciertas constantes: se dibuja un destino y se contribuye a una reconstrucción; es decir, se traza un esbozo renovado de la torre de Babel que abolió 
la predominancia del hebreo, el único idioma universal porque divino, el de la Biblia y los judíos del antiguo Israel y propició con ello la dispersión y el ruido causado por la confusión de las lenguas; y se juega a una reconstrucción, la de un sintético tejido judío compuesto en otras circunstancias territoriales y lingüísticas.

La organización textual hace casi imposible reconocer a los autores, los colaboradores aparecen alfabetizados en el índice y por capítulos, pero sus nombres no remiten a una paginación que permita localizarlos, hay sólo un encabezado para identificar el fragmento, lo que obliga a un constante ejercicio de localización, como si el libro fuera una lanzadera o un camino de ida y vuelta con sus recovecos, o hasta un círculo vicioso. Una vez familiarizado el lector con la especial organización del volumen, es posible manejarlo con más tranquilidad y empezar a entender el sentido de la compilación y a jugar con sus posibilidades combinatorias. Barthes dice en alguno de sus libros:

En la obra literaria no hay más significado primero que un cierto deseo: escribir es un modo del Eros. Pero este deseo, en principio, sólo tiene a su disposición un lenguaje pobre y vulgar; la afectividad que hay en el fondo de toda literatura sólo comporta un número irrisoriamente reducido de funciones...La afectividad es trivial, o por decirlo así, típica, y ello determina todo el ser de la literatura; pues si el deseo de escribir sólo es la constelación de unas cuantas figuras obstinadas, al escritor sólo le resta una actividad de variación y de combinación; nunca hay creadores, sólo combinadores, y la literatura es semejante a la nave Argos: a pesar de estar obligada a una función inmóvil, cada pieza se renovaba infinitamente, sin que el conjunto dejara nunca de ser la nave Argos... (215).

Lo reitero: este libro modifica el procedimiento habitual con que se compilan las antologías, de las cuales hay varias en la América judía , pero ninguna tan extensa ni tan plural, pues el lector va captando poco a poco el material que de manera desmesurada aparece ante sus ojos y para ello tiene que aventurarse siguiendo nuevos caminos de lectura. Los textos adquieren una extraña lisura, como si las experiencias de cada uno de los escritores careciese de territorialidad definida, como si las experiencias fuesen las mismas, una extraña reiteración renovada, combinada, la persistencia de ciertas miradas y de ciertas acciones, de algunos gestos, una viaje circular que conduce de Ucrania, Polonia, Bielorrusia, Lituania, Rusia o Turquía a Buenos Aires, Río, La Habana, México, Caracas, Bogotá, Lima, Quito. Los mismos viajeros, los mismos hermanos de barco, las mismas ropas raídas, las mismas esperanzas, las barbas puntiagudas, la mirada desolada, la misma sorpresa y el mismo deseo de encontrar la maravilla, la tierra prometida, siempre presente en el imaginario judío. Y las voces se reúnen y aunque algunos hablen polaco y otros ruso y otros griego, casi siempre idish o ladino junto al hebreo, el sonido es igual, tanto que se pensaría que en el trayecto que conduce a los emigrantes de su antigua tierra inhóspita -lugares de pogroms y discriminaciones - a la nueva diáspora anhelada, se hubiese recobrado el idioma primigenio, el idioma universal que gobernaba al mundo antes de que la discordia construyese la Torre de Babel. 
LA TERRITORIALIZACIÓN Y SUS FIGURAS

La llegada desterritorializa, sin embargo. Los antologados describen el sentimiento de desamparo de quienes desembarcan en las nuevas tierras prometidas, el desconocimiento del nuevo idioma, la violencia de un nuevo clima y un nuevo paisaje, las peripecias de la reterritorialización, nuevas combinatorias, el establecimiento de un sistema inédito de conexiones. Deleuze y Guattari, hablando de Kafka dicen justamente al respecto:

Ciertas series se componen de términos especiales. Estos mismos términos se distribuyen en las series ordinarias, al principio de una y al fin de otra, y marcan así la manera en que se encadenan, se transforman y proliferan, la manera cómo un segmento se agrega a otro o nace del otro. Estas series especiales están hechas entonces de elementos notables que sirven como transmisores, porque aumentan en cada conexión —podríamos también llamarlas combinación — las relaciones entre el deseo y el campo de inmanencia (115).

Hacer suyos, apoderarse, apropiarse de los textos de los otros, mediante este trabajo de fragmentación y de resemantización, eso hace Goldemberg, pone de manifiesto en su nuevo ensamblaje un cierto patrón reiterado: la emigración, ese exilio, esa diáspora perpetua- engendra patrones de conducta y aunque cada autor piensa que habla de su experiencia como si fuese única y singular —y así lo es para cada uno de los escritoresla trama dibuja un texto que colectiviza , universaliza la experiencia. El dibujo trazado es aparentemente simple. Parecería que no hay cosa más fácil de reconocer que un exilio. Ahora bien, ¿quién podría decir que ese discurso está compuesto de tantas voces disímbolas y distantes las unas de las otras?, ¿cómo reconocer — guardando las proporciones - la voz de los reyes, los jueces o los profetas?, ¿quién es Jeremías y quién Amós?, ¿o David o Salomón? Desconcierta esa inevitable relación entre las figuras que desdibujan a los autores individuales mientras se subraya el tramado que han tejido las operaciones combinatorias. Sin embargo, después de verificar la semejanza, el sentimiento colectivo, la experiencia unánime, como en cualquier intrincado dibujo, las figuras pueden irse reconociendo como se reconocen sueltas las piezas de un rompecabezas, las voces empiezan a recobrar su identidad y el lector también recompone los matices y los identifica, no sólo porque se mencionen ciertas ciudades y sus calles, las costumbres y comidas regionales que se superponen a las que traen con ellos los inmigrantes, sino porque la forma de manejar la lengua -insisto, no tanto por los coloquialismos - sino por una cierta sintaxis singular.

Así, de repente, y sin advertirlo las voces son familiares. Oigo al argentino Sergio Chejfec, sin buscarlo siquiera en el índice, lo reconozco por su entonación y por ciertas anécdotas que cuando lo conocí me refirió. Voy descifrando, sin recurrir a lo obvio, las figuras. También reconozco la voz de mi amiga mexicana Esther Seligson. En algunas de sus frases se advierte una inflexión talmúdica, un pensamiento enunciado con gran lirismo y sin embargo con rigor, una manera de hilar, como ella misma dice, las hebras del tejido. Reconozco asimismo la voz de Luis Mario Schneider, es su Arponero del Fuego, poema de un argentino publicado en México. Es de repente posible y fácil reconocer las voces, ya cercanas, tan oídas, murmuradas casi al oído, pero cosa curiosa, no me fue fácil reconocerme a mí misma y me busco con esfuerzo y allí estoy, casi no me veo, estoy al lado, casi 
confundida, con alguien a quien no conozco, Haim Horacio López Peña, jamás había oído hablar de él y mis palabras son en realidad las suyas, y las suyas en parte las mías, una forma de justicia poética, la verificación de que el lenguaje es de todos como diría Borges o de que el lenguaje habla a través de nosotros, no sólo justicia poética sino abolición del ego. Y en esta dinámica de nunca acabar, en estos vaivenes en donde las voces se pierden para recuperarse poco tiempo después en sonidos nítidos paso revista y delineo un nuevo viaje, un viaje que en 1983 nos reunió en Israel a varios de los que estamos antologados, el propio Goldemberg, David Tarkeltaub, Rosita Kalina, Teresa Porzekanski, Marcos Ricardo Barnatán, Moacyr Scliar, etc., y volvemos a reencontrarnos, estamos de nuevo traspasando las fronteras, reconociéndonos, reubicándonos.

Más tarde, en ese mismo libro, encuentro a Alicia Steimberg, viajera, cuentista, novelista erótica, o a Juan Gelman, gran poeta que por esos mismos azares del destierro latinoamericano doblado por la errancia judía vino a recalar a México donde continúa escribiendo como en su otra tierra, Argentina, y libra batallas contra los fascismos.

Trataré de explicarlo, echando mano de un texto de Foucault en su libro sobre Magritte, Esto no es una pipa:

\footnotetext{
El texto que había invadido la figura con el fin de reconstituir el viejo ideograma, vemos que ha vuelto a colocarse en su sitio. Ha vuelto a su lugar natural ... Del pasado caligráfico, que estoy obligado a asignarles, las palabras han conservado su pertenencia al dibujo y su estado de cosa dibujada: son palabras que dibujan palabras; forman en la superficie de la imagen los reflejos de una imagen que diría que esto no es una pipa (35-36).
}

\section{BiBLIGRAFÍA}

Barthes, Roland. Ensayos críticos. Barcelona: Seix Barral, 1967.

Deleuze, Gilles y Jacques Guattari. Kafka, pour une littérature mineure. París: Minuit, 1972.

Foucault, Michel. Esto no es una pipa. Barcelona: Anagrama, 1987. 